\title{
Gunungkidul Traditional Food Inventory as a Preservation Efforts for Local Products to Facing Globalization
}

\author{
Catarina Wahyu Dyah Purbaningrum, Rosalia Widhiastuti Sri Lestari \\ $\left\{\right.$ Catarinaᄀ_dyah@yahoo.com¹ ${ }^{1}$,rosalia_widhiastuti@yahoo.co.id $\left.{ }^{2}\right\}$ \\ Universitas Gunung Kidul, Yogyakerta, Indonesia ${ }^{1,2}$
}

\begin{abstract}
Globalization has a significant influence in people's lives, especially in changing people's taste for food taste. This study aims to: (1) A detailed inventory of traditional foods in Gunungkidul Regency, (2) How is the prototype of a book about traditional foods found in Gunungkidul Regency. This research includes survey research with descriptive methods. This research survey was conducted in traditional markets, culinary markets and culinary experts. From the results of the study it can be identified that Gunungkidul has 81 (eighty one) types of traditional food. The method of processing traditional food in Gunungkidul is done in four ways, namely 25 (twenty five) types of food processed by frying, 22 (twenty two) types of boiled food, 30 (thirty) types of steamed food, and 4 (four) roasted foods. Improved quality is needed in terms of taste, appearance and packaging in order to be able to compete with modern food products on the market.
\end{abstract}

Keywords: Inventory, traditional food, gunungkidul.

\section{Introduction}

Food is one of the cultural works of the society. All humans need food to survive, therefore food is a basic need that must be met. Food is usually produced from food after it is first processed or cooked [1]. Traditional food is a reflection of the diverse cultures and traditions of the archipelago and holds an important place in Indonesia's national culture. Basically there is no single form of Indonesian cuisine, but rather a diversity of regional cuisine that is influenced locally by Indonesian culture and foreign influences.

The way people prepare their daily dishes is probably one of the most important direct interactions between things related to culture and nature [2]. Diversity of food with all of the ingredients is culturally diverse throughout the world. The history of how people eat food is culturally and biologically rooted [3]. Socially, food also plays a major role. Many analyzes have illustrated the relationship between food and food, social life that is formed causally, tradition, and daily life causally [4]. Social interaction can change the way people prepare food and drinks, from the process of cultural assimilation, to economic processes due to industrial and global processes [5].

Traditional foods are food (including snacks) and drinks and ingredients (ingredients) that have traditionally been used and developed in Indonesian regions or communities [6]. Some snacks are classified as traditional foods that have undergone development. Traditional food is one of the cultural assets that must be explored as one of the cultural assets through revitalization and transformation processes. Each group of people has their own unique way of presenting 
their food, and that may signal a particular way of life. Mapping traditional foods can reflect ethnographic features [7]. Studying food diversity has the potential to bring us more insight into anthropological understanding and social complexity [8]. This needs to be done to offset the arrival of foreign food and culinary franchise models as the impact of free markets and globalization. Traditional foods in Indonesia are increasingly unpopular and even sink and lose to foreign foods that are increasingly entering Indonesia. By looking at this phenomenon, there should be an effort to re-popularize both the government, business actors and the wider community.

Globalization has a significant influence in the lives of Indonesian people, especially on changing people's taste for food taste. This impact forms a mindset and behavior that is different from society in the past. It is undeniable that the inheritance of traditional recipes in the past has not received much attention from the public, especially the younger generation. The possibility of this phenomenon occurs because the view of traditional inheritance is an outdated culture, even though when observed traditional cuisine has a profound meaning about the culture of the past society. Food and drink are not only about consumption but many aspects where food is prepared [9]. Traditionally, certain foods and drinks have implicit meanings, related to health maintenance, preventing disease, and behavior during abundance or scarcity of food [10]. Food and beverages in traditional culture have become integrated cultural elements and can be seen as a reflection of a kind of "living art" [11].

Gunungkidul's typical food is very necessary to be preserved, thus creating a superior product that deserves to be proud of as one of the culinary riches. The Gunungkidul people themselves only know some of the Gunungkidul specialties, so it is necessary to promote Gunungkidul traditional food through books, so that using this book is expected to preserve local products as one of the cultural riches.

Up to now the mapping of the ingredients in the traditional food productions in Gunungkidul Regency has not been well identified. Therefore, the study aims to identify the use of local raw materials of traditional food producing in Gunungkidul Regency. This identification is the first step to determine the potential use of local raw materials in the manufacture of traditional food in Gunungkidul in order to improve and promote local food development. This inventory is carried out in the domestic market and village market in all districts in Gunungkidul Regency. The results of this identification are also expected to be a data base on the use of local raw materials in the manufacture of traditional food in Gunungkidul Regency

\subsection{Literature Review Food}

Food is a basic human need and was first ranked among a range of other needs according to Maslow. Every individual needs a number of foods to maintain their survival. By economists, food is used as an indicator of the level of community welfare. Food is a very important part of culture [12].

Food is needed for life because food is one of the basic needs for human life. Food serves to maintain the body's processes in growth or development and replace damaged body tissues, obtain energy to carry out daily activities, regulate metabolism and various balances of water, minerals, and other body fluids, also play a role in the body's defense mechanisms against various disease [13]. 


\subsection{Traditional Food}

Traditional food is a type of food that is closely related to an area which inherited from the last generationto the next generation as part of tradition [14]. Traditional food is a product that is often consumed by a group of people or served at celebrations and at certain times, passed down from generation to generation, made according to recipes for generations, made without or with little engineering, and has certain characteristics that distinguish it from other regional culinary [15].

Traditional foods can also be defined as common foods consumed for peoples, consisting of dishes to suit human tastes, not against the local religious beliefs, and made from locally available food and spices [16].

Traditional food as food consumed by ethnic groups and specific regions, processed based on recipes that have been passed down from generation to generation. The raw material used comes from the local area so that the food produced is also in accordance with the tastes of the community [17].

\subsection{Local Food}

Local food is food that has long been produced, developed and consumed in an area or a certain local community group. Generally local food products are processed from local ingredients, local technology and local knowledge as well. In addition, local food products are usually developed according to local consumption preferences as well, so that local food products are closely related to local local culture. The variety of local food has the potential as an alternative substitute for rice. For example, in Papua there are a number of local local foodstuffs that have long been used by local communities as raw materials for substituting rice, such as sweet potatoes, taro, sago, gembili, and jawawut. Local food products have adapted well and consumed by the Papuan people for generations. In addition to Papua, some local foods that have been used by the community as rice substitutes are corn in Madura and Gorontalo [18].

\subsection{Market}

Market in the economic side is the situation of a person or more buyers (consumers) and sellers (producers and traders) were gathering regularly to make transactions after both of them have taken an agreement about the price of a number (quantity) of goods with certain qualities that are the object of the transaction. Both of them, the buyer and seller get the desired item to fulfill and satisfy their needs while the seller gets a return for income which is then used to finance his activities as a production economy trader or trader [19].

The market is an area of sale and purchase of goods with a number of sellers of more than one, both called shopping centers, traditional markets, shops, malls, plazas, trade centers and other named [20]. According to the Minister of Trade of the Republic of Indonesia, the Market in the sense of economic theory is a situation of one or more buyers (consumers) and sellers (producers and traders) making transactions after both parties have taken an agreement on the price of a number (quantity) of goods with a certain quantity that becomes transaction object. Both parties, buyers and sellers, benefit from transactions or markets. The buyer gets the desired item to fulfill and satisfy his needs while the seller gets an income reward to be used to finance his activities as a production economy trader or trader. 


\subsection{Pasar Tradisional}

Traditional markets as markets that are built and managed by the Government, Regional, Private, State-Owned Enterprises and Regionally-Owned Enterprises including cooperation with the private sector with businesses, shops, kiosks, stalls and tents owned / managed by small, medium, community self-help or cooperatives with small-scale businesses, small capital and the process of buying and selling merchandise through bargaining [20].

\subsection{Globalizations}

Waters has said that globalization is a social process, where geographical boundaries are not important to socio-cultural conditions, which eventually manifests into one's consciousness [21]. Whereas according to Giddens globalization is the existence of interdependence between one nation and another, between one human being and another through trade, travel, tourism, culture, information, and broad interaction so that the boundaries become increasingly narrow [22].

The nature and scope of the influence of globalization that can be discussed depends on the meaning given to the term globalization itself. And it needs to be understood that the meaning of globalization is a "source of influence", while the "recipient of influence" is all aspects of life. [23]. There are several cultural categories that have undergone a process of globalization, one of which is the culture of eating. Various types of western foods and drinks have been enjoyed and are increasingly popular throughout the world. In fact, Japanese food has also been accepted by Malaysians such as Spaghetti, pasta, soft drinks like Coca Cola is not a foreign object anymore in the world [24].

\section{Research Methods}

This type of research is survey research with descriptive studies. Survey research is research that collects data at certain times with three important objectives, namely to describe natural conditions, identify measurably and determine the relationship of a living thing [25]. The location of the study was conducted in all traditional markets that operate routinely in each subdistrict in Gunungkidul Regency. In this study the population was all traditional food vendors in 106 markets in Gunungkidul Regency. Of the 106 populations, the number of samples used in this study were 84 respondents of traditional food traders.

Data collection techniques used in this study are interviews with traditional food traders who sell in traditional markets, observation and recording of traditional foods sold in traditional markets, culinary snacks centers and information from traditional food experts Gunungkidul. Methods of data analysis in this research through three stages, namely data reduction, data presentation and conclusion drawing.

\section{Discussion}

From the results of identification of traditional foods in each sub-district in Gunungkidul Regency, there were many similarities between regions. This indicates that cultural patterns and food taste patterns in each sub-district in Gunungkidul are almost the same. The types of 
traditional foods found in traditional markets, culinary markets and information from informants found that in Gunungkidul there were 84 (eighty four) types of food, namely: 1) Alakatak 2) agar-agar karangan (rumput laut), 3) apem goreng, 4) apem conthong, 5) arem-arem, 6) ayungayung, 7) bakmi jawa, 8) belalang goreng, 9) bendrat, 10) beras kencur. 11) blondho, 12) bongko, 13) bothok laron, 14) brangkal, 15) brondong jagung, 16) cemplon, 17) cengkaruk 18) cenil 19) cethil, 20) cucur, 21) emping gerut, 22) emping mlinjo, 23) emping ketela, 24) entung goreng, 25) gandhos, 26) gathot, 27) gembili, 28) gethuk, 29)gudhangan, 30) gudheg nangka, 31) gudheg daun pepaya, 32) jadah gemblong, 33) Jangan Lombok ijo, 34) jenang sunsum, 35) kacang godhog 36) karak, 37) kedelai godhog, 38) kewat, 39) kicikan, 40) kimpul, 41) klepon, 42) krecek ketela (manggleng), 43) kue coro, 44) kunir asem, 45) lapis, 46) lempeng ketela, 47) lemper, 48) lemet, 49) lopis, 50) mendhut, 51) meniran, 52) mie pentil, 53) nagasari, 54) ondeonde isi, 55) pathilo, 56) peyek gereh, 57) pisang godhog, 58) puli tempe, 59)rengginang, 60) sambel cabuk, 61) sagon, 62) semar mendhem, 63) sengkulun, 64) serabi, 65) sego abang, 66) sego jagung, 67) sompil, 68) srundeng, 69) tape ketan, 70) tape telo, 71) tempe kedelai bacem, 72) tempe benguk, 73) tempe gembus, 74) tempe manding, 75) timus, 76) thiwul, 77) kimpul, 78) utri, 79) uwi, 80) uyub-uyub, 81) wajik klethik.

There are 25 (twenty-five) food processing methods for traditional food, cooked by frying, 22 (twenty-two) foods cooked by boiling, 30 (thirty) foods processed by steaming and 4 (four) foods processed by means of roasted.

The economic value of traditional food in Gunungkidul when compared to modern food circulating in the market is relatively cheap. Thus, efforts should be made to develop Gunungkidul traditional food both in quality and packaging so that it has higher competitiveness and selling power, at least it can compete with modern food in the same market.

\section{Conclusion}

From the survey results obtained data that there are 81 (eighty one) traditional foods found in the traditional market of Gunungkidul, then the food needs to be preserved so as not to be displaced by modern foods on the market.

Need to improve the good quality in terms of taste, shape and packaging so that traditional food is more attractive so that it can compete with modern food products that have been competitors.

In terms of economic value, Gunungkidul's traditional food is still relatively cheap, therefore it is necessary to improve the quality and development of products, in addition to making these foods have competitiveness with modern products but can also increase the income of MSMEs that produce them. regional or community in terms of increasing consumption of local food.

\section{References}

[1] S. Soekarto, Dasar-dasar Pengawasan dan Standarisasi Mutu Pangan. Bogor IPB: PAU-Pangan dan Gizi., 1990.

[2] M. Montanari, Food is Culture. Sonnenfeld, A. Columbia UP, 2004.

[3] G. . Nabhan, Food, genes, and Culture: eating right for your origins. Island Press., 2004.

[4] C. Counihan and V. E. P, Food and Culture: A Reader. Brooks. P, Trans. 2nd. Routledge, 2008.

[5] A. M. E, "Authentic or not, It's original."Food and Foodways: Explorations in the History and Culture of Human Nourishment," vol. 12, pp. 1-25, 2004. 
[6] Anonim, Panduan Pusat Kajian Makanan Tradisional. Kantor MenPangan. jakarta: Debdikbud, 1996.

[7] A. P. Van Liere, M. J., Brouwer, I. D., den Hartog, "A food ethnography of the Ottamari in northwestern Benin: A systematic approach.,” Ecol. Food Nutr., vol. 34, p. 293-310., 1996.

[8] D. E. Sutton, Remembrance of Repasts: an Anthropology of Food and Memory. Bloomsbury Academic., 2001.

[9] P. Fieldhouse, Food and Nutrition: Customs and Culture 2nd. Springer Science+Business Media Dordrecht. 1995.

[10] R. S. Khare and M. C. P. A. Rao, Food, Society, and Culture: Aspects in South Asian FoodSystems. Carolina Academic Press., 1986.

[11] J. A. Hegarty and G. B. O'Mahony, "Gastronomy: a Phenomenon of Cultural Expressionism and an Aesthetic for Living," Int. J. Hosp. Manag., vol. 20, p. 3-13., 2001.

[12] A. Khomsan, Pangan dan Gizi Untuk Kesehatan. jakarta: PT Raja Grafindo Persada, 2003.

[13] S. Notoatmodjo, Pendidikan Dan Perilaku Kesehatan. jakarta: Rineka Cipta, 2003.

[14] M. Pieniak, Z., Verbeke, W., Vanhonacker, F., Guerrero, L., \& Hersleth, “Association between Traditional Food Consumption and Motives for Food Choice in Six European Countries.," Appet. J., vol. 53, pp. 101-108, 2009.

[15] M. Guerrero, L., Claret, A., Verbeke, W., Enderli, G., Biemans, S.Z., Vanhonacker, F., Issanchou, S., Sajdakowska, M., Granli, B.S., Scalvedi, L., Contel, M., Hersleth, "Perception of Traditional Food Products in Six European Regions Using Free Word Association," Food Qual. Prefer., vol. 21, pp. 225 233, 2010.

[16] S. Sastroamidjojo, Makanan Tradisional, Status Gizi, dan Produktivitas Kerja. jakarta: Kantor Menteri Negara Urusan Pangan., 1995.

[17] Hadisantoso, "Makanan Tradisional yang Memiliki Kandungan Gizi dan Keamanan yang Baik," in seminar Pengembangan Pangan Tradisional dalam Rangka Penganekaragaman Pangan, 1993.

[18] A. W. Rauf and M. S. Lestari, "Pemanfaatan Komoditas Pangan Lokal Sebagai Sumber Pangan Alternatif Di Papua,” Balai Pengkajian Teknologi PertanianPapua.

[19] M. P. R. Indonesia, No Title. .

[20] Depdiknas, Peraturan Presiden Nomor 112 Tahun 2012 tentang Penataan dan Pembinaan Pasar Tradisional, Pusat Tradisional, Pusat Perbelanjaan dan Toko Modern. .

[21] M. Waters, Globalization, 2nd Editio. London: Taylor and Francis Group, 1995.

[22] A. Giddens, The Consequences of Modernity. Cambridge: Polity Press, 1990.

[23] B. Osman, "Pengaruh Globalisasi Terhadap Peradaban,” J. Perad., pp. 75-98, 2008.

[24] M. . Azhar, "itas Kertas 1: Tamadun Melayu dan Tamadun Islam. Fajar Bakti Sdn.Bhd. Shah Alam. Amriah, B. 2005. Globalisasi ekonomi dan impaknya kepada ruang budaya bandar Malaysia.," Malaysian J. Soc. Sp. 1.

[25] Sukardi, Metodelogi Penelitian Pendidikan. Yogyakarta: bumi aksara, 2011. 